\title{
Friendships Moderate an Association between a Dopamine Gene Variant and Political Ideology
}

\section{Citation}

Settle, Jaime E., Christopher T. Dawes, Nicholas A. Christakis, and James H. Fowler. 2010. Friendships moderate an association between a dopamine gene variant and political ideology. The Journal of Politics 72(4): 1189-1198.

\section{Published Version}

doi:10.1017/S0022381610000617

\section{Permanent link}

http://nrs.harvard.edu/urn-3:HUL.InstRepos:8852312

\section{Terms of Use}

This article was downloaded from Harvard University's DASH repository, and is made available under the terms and conditions applicable to Other Posted Material, as set forth at http:// nrs.harvard.edu/urn-3:HUL.InstRepos:dash.current.terms-of-use\#LAA

\section{Share Your Story}

The Harvard community has made this article openly available.

Please share how this access benefits you. Submit a story.

Accessibility 


\title{
Friendships Moderate an Association between a Dopamine Gene Variant and Political Ideology
}

\author{
Jaime E. Settle University of California, San Diego \\ Christopher T. Dawes University of California, San Diego \\ Nicholas A. Christakis Harvard University \\ James H. Fowler University of California, San Diego
}

\begin{abstract}
Scholars in many fields have long noted the importance of social context in the development of political ideology. Recent work suggests that political ideology also has a heritable component, but no specific gene variant or combination of variants associated with political ideology have so far been identified. Here, we hypothesize that individuals with a genetic predisposition toward seeking out new experiences will tend to be more liberal, but only if they are embedded in a social context that provides them with multiple points of view. Using data from the National Longitudinal Study of Adolescent Health, we test this hypothesis by investigating an association between self-reported political ideology and the $7 R$ variant of the dopamine receptor D4 gene (DRD4), which has previously been associated with novelty seeking. Among those with DRD4-7R, we find that the number of friendships a person has in adolescence is significantly associated with liberal political ideology. Among those without the gene variant, there is no association. This is the first study to elaborate a specific gene-environment interaction that contributes to ideological self-identification, and it highlights the importance of incorporating both nature and nurture into the study of political preferences.
\end{abstract}

I his influential collection of essays, Ideology and Utopia, Karl Mannheim (1936) sought to explain the meaning and origin of political ideology. As a founder of the "sociology of knowledge" school of thought, he broadened a view, first championed by Marx, that individual political attitudes are derived from groups and their relationships to the whole of society. While Marx focused particularly on class relations, Mannheim observed that political ideology is the product of the total social context of each individual. To understand a person's political ideology, we need only examine his or her political environment.

Mannheim's work would influence several generations of scholars (e.g., Bell 1959; Haas 1992; Huntington 1957; Lipset 1983; North 1978; Rapoport 1974). While many of these scholars disagreed with parts of Mannheim's argument, they all agreed with the premise: that the social and institutional environment is paramount for explaining a person's political attitudes and beliefs. When individuals say they are "liberal" or "conservative," they are referring to their ideas about the issues of the day that are specific to a place and a moment in history. Remove them to another context and their ideology will change.

This literature contrasts with a growing body of work that suggests ideology is not purely a product of the social environment or historical moment. Increasingly, it is becoming apparent that political ideology also has a "core" element that is rooted in innate predispositions, personality, and "motivated social cognition" (Jost et al. 2003). In fact, psychologists have asserted for many years that social conservatism is heritable (Bouchard and McGue 2003; Cloninger, Svrakic, and Przybeck 1993; Eaves and Eysenck 1974) and that genetic factors account for a significant proportion of variation in social attitudes (Martin et al. 1986; Tesser 1993). Alford, Funk, and Hibbing (2005) were among the first to present these findings to the political science discipline, showing that genetic variation helps to explain both the direction (liberal vs. conservative) and strength of ideological opinions in a very large sample of twins. Since then, scholars have found that political attitudes related to vote choice are also heritable (Hatemi et al. 2007) as is the strength of 
partisan attachment (Hatemi et al. 2009a; Settle, Dawes, and Fowler 2009). Likewise, genetic variation is important for explaining variation in political behaviors that are known to be influenced by ideology, like voting and other forms of political participation (Fowler, Baker, and Dawes 2008; Fowler and Dawes 2008; Dawes and Fowler 2009). These findings suggest that we should revise our environment-only understanding of political attitudes and ideology. Political ideology is rooted in general social psychological tendencies and has heritable and durable components that may be constrained or exacerbated by the influence of the social context.

Social and genetic theories about the nature and origin of political ideology need not be at odds with one another. In fact, it is likely that genes influence political ideology by partially regulating the way we react to the total social context. If so, then one way forward in our understanding of the biological and social bases of political attitudes and beliefs is to search for specific gene-environment interactions that may play a role in the development and maintenance of political ideology. Behavior geneticists note that complex social behaviors are polygenic (Mackay 2001; Plomin 2008); likewise there are probably many gene-environment interactions that play a role in the acquisition of political ideology. A logical way to start our search is to examine gene variants that are already known to contribute to variation in social behaviors that are related to political ideology. One such gene is the D4 dopamine receptor gene (DRD4), which regulates dopamine activity in the brain (Cloninger, Svrakic, and Przybeck 1993; Wiesbeck et al. 1995). The 7R allele of this gene has been associated with novelty-seeking behavior (Auerbach et al. 2001; Benjamin et al. 1996; Benjamin et al. 2000; De Luca et al. 2001; Ebstein et al. 1996; Noble et al. 1998; Schmidt et al. 2002; Strobel et al. 1999; Tomitaka et al. 1999), which is a tendency that is related to openness (De Fruyt, Van De Wieleb, and Van Heeringen 2000), a psychological trait that has been associated with political liberalism (Jost et al. 2003; Pratto et al. 1994; Peterson and Lane 2001; Peterson, Smirles, and Wentworth 1997). This prior research suggests one possible pathway from genes to personality to ideology, but it does not consider the important role of social context. We therefore investigated how the $7 \mathrm{R}$ allele might interact with an important social variable: the number of friendships a person forms.

This article is the first to identify a specific geneenvironment interaction that is associated with the direction of a person's ideological self-identification.
We show that among those who carry the $7 \mathrm{R}$ allele of the $D R D 4$ gene, the number of friends a person has in adolescence is positively associated with liberal selfidentification in early adulthood. Among those who do not carry the $7 \mathrm{R}$ allele, there is no relationship between number of friends and ideology. Moreover, we show that the $7 \mathrm{R}$ allele is not directly associated with the reported number of friends, nor is it directly associated with ideology. Instead, it is the combination of this specific gene variant with a specific social environment that may contribute to the development of a liberal political ideology.

\section{Ideology: Past Research and Support for a Genetic Basis}

We define ideology as a general belief system that encompasses a wide set of idea-elements that come together in a nonrandom fashion (Converse 1964; Gerring 1997). Here, we refer more specifically to the liberal-conservative continuum commonly understood as organizing American politics (Treier and Hillygus 2005). It has been long debated whether ideology is rooted in issue preferences (Converse 1964) or whether ideological labels are symbolic and affect-oriented (Conover and Feldman 1981). Early studies suggest that Americans have little constraint in their ideology, that they have few opinions about public policy or political parties, that their opinions on policy change frequently, dramatically, even randomly, and that they have limited capacity to process political information (Campbell et al. 1960; Converse 1964). These early findings have been critiqued from both a methodological and conceptual perspective, and the general consensus has been that the public is not particularly ideological or sophisticated, but neither is it totally unreasoning nor unopinionated (Sniderman, Brody, and Tetlock 1993). Ideological labels are more salient (Hinich and Munger 1997; Holbrook 1996; Treier and Hillygus 2005) and more meaningful as party leaders and elites polarize (Abramowitz and Saunders 1998; Hetherington 2001; Hinich and Munger 1997; Jacobson 2003; McCarty, Poole, and Rosenthal 2006; Schreckhise and Shields 2003). They are also useful (Jacoby 2004; Lau and Redlawsk 1997), even if not everyone precisely agrees on what the terms "liberal" and "conservative" mean.

Furthermore, there is a strong association between parental and offspring political attitudes. With few exceptions past scholars have attributed this to 
the environmental influences and political socialization to which parents expose their children (Jennings and Niemi 1968). However, recent evidence from a series of twin and extended kinship studies suggests that the mechanism by which parents pass their ideology to their children may in part be due to heredity, and that political attitudes themselves are genetically influenced (Alford, Funk, and Hibbing 2005; Eaves and Hatemi 2008; Hatemi, Medland, and Eaves 2009b; Tesser 1993). Studies based on large samples of twins from the United States, the United Kingdom, and Australia find that at least a third of the variation in political attitudes can be accounted for by genes and approximately half of the variation can be explained by unshared environment. Hatemi et al. (2007) replicated these results using an extended family design that includes parents and nontwin siblings. But no study has yet identified specific genes that are associated with ideology.

\section{Dopamine and DRD4-7R}

Dopamine, a member of the catecholamine family, is one of many different types of neurotransmitters which can be found in the brain, each with different functions. The D4 dopamine receptor DRD4 (one of five subtypes of dopamine receptors) is a protein transcribed by a gene with the same name (DRD4). This gene is commonly described by at least three polymorphic variations in its coding sequence (Van Tol et al. 1992), including the allele of interest in this study, the long form allele (7R). Among other behaviors, novelty seeking is thought to be mediated by genetic variability in dopamine transmission (Cloninger, Svrakic, and Przybeck 1993). A wide variety of genetic association studies have tested the link between polymorphisms of DRD4 and noveltyseeking behavior with generally positive results (Kluger, Siegfried, and Ebstein 2002; Savitz and Ramesar 2004; Schinka, Letsch, and Crawford 2002). There are several proposed mechanisms, most of which are related to the manner and frequency with which dopamine binds to its receptors. ${ }^{1}$

Studies of animals indicate that DRD4 is involved in cortical excitability and behavioral sensitization.

\footnotetext{
${ }^{1}$ Most recent version of paper and online appendix available at http://journals.cambridge.org/JOP and at http://jhfowler.ucsd.edu. Data necessary to reproduce the numeric results in the paper are available at http://www.icpsr.umich.edu/DSDR/addhealth/index. html. More information about the dopamine system, the DRD4 dopamine receptor, and the association between DRD4 and behavioral traits can be found in the online appendix at http:// jhfowler.ucsd.edu.
}

These alterations in cortical arousal affect "approach traits" such as novelty seeking and sensation seeking, which in turn affect personality and behavior (Eichhammer et al. 2005). People who score high on measures of novelty seeking have less tolerance for monotony and constantly seek the new and unusual (to them) in order to alter dopamine levels to affect mood; at the extremes, they are characterized as impulsive, exploratory, fickle, excitable, quick-tempered, and extravagant (Puttonen, Ravaja, and Keltikangas-Jarvinen 2005). People who score low on this measure tend to be more inclined to follow the rules (Golimbet et al. 2007). Those who score lower also tend to be more reflective, rigid, loyal, stoic, slowtempered, and frugal.

\section{Novelty Seeking, Friends, and Liberalism}

Certain situational and dispositional factors may contribute to a cognitive-motivational orientation toward the social world that is either closed and invariant or open and exploratory (Kruglanski and Webster 1996). In fact, "openness to experience," a construct conceptually related to novelty seeking, is the personality trait most commonly linked to political orientations (Cornelis et al. 2009; Jost et al. 2003; McCrae 1996; Mondak and Halperin 2008) and has been found to be negatively related to political conservatism generally (Van Hiel, Kossowska, and Mervielde 2000) and sociocultural conservatism specifically (McCrae 1996; Peterson, Smirles, and Wentworth 1997; Trapnell 1994; Van Hiel, Kossowska, and Mervielde 2000). The relationship between openness to experience and ideology holds when ideology is measured either as support for ideological political parties (Caprara, Barbaranelli, and Zimbardo, 1999; Van Hiel, Kossowska, and Mervielde 2000) or as ideological self-placement (Carney, Jost, and Gosling 2008; Van Hiel, Kossowska, and Mervielde 2000). The connection between openness to experience and ideology may even stem from the same genetic constructs: Verhulst, Eaves, and Hatemi (2009) suggest that the relationship between personality and political preferences is the result of shared genetic influence.

However, we argue that the DRD4-7R allele cannot by itself predispose someone to a liberal ideology. It requires a context in which people are exposed to certain social environments. Here, we focus on the number of friendships a person has because this is an essential measure of a person's 
social context. Psychologists have found that friendships promote growth in social cognition and selfconcept (Staub 1995), increase feelings of social belonging (Bishop and Inderbitzen 1995), increase self-esteem (Bishop and Inderbitzen 1995), promote a better understanding of others' needs, foster mutual trust (Neibrzydowski 1995), encourage greater consideration in regard to society (Selman 1990, White et al. 1987), and promote prosocial behavior (Hartup 1983). For people who like new experiences, friendships thus serve to expose a person to the sociopolitical world, perhaps activating a political ideology that psychologically satisfies an openness to change and new experience.

Additionally, an increased number of friends may expose a respondent to a wider diversity of viewpoints. Although social networks are known to be homophilous (McPherson, Smith-Lovin, and Cook 2001), Huckfeldt, Johnson, and Sprague (2004) demonstrate that significant political disagreement persists between friends, suggesting that the more friends people have, the more likely they are to regularly engage with at least one person with a different point of view. And although disagreement might result in more political ambivalence and less political engagement (Mutz 2002), it does not reduce the intensity of a person's political opinions (Huckfeldt, Johnson, and Sprague 2004, 203). Adolescents are in the process of learning about the social world; therefore they are being shaped by a wide variety of influences. Those who have more friends are exposed to more new experiences in childhood (Heiman 2000). For adolescents who are innately novelty seeking, a natural tendency toward openness to experience may create psychological satisfaction derived from novel experiences, including the desire to learn about and understand multiple points of view from one's friends.

Finally, it is well known that peers and friends exert an influence on political preferences (Berelson, Lazarsfeld, and McPhee 1954), and recent work suggests that informal components in the school environment, such as the influence of peer attitudes, contribute to political socialization (Settle, Bond, and Levitt forthcoming).

For these reasons, we hypothesize that the combination of an innate desire for novel experience and many friends may contribute to the activation of a liberal ideology. People who have many friends may nonetheless remain uninterested in their friends' point of view. Alternatively, people who crave new experiences may not get them from their social context if they have only a few friends. It is the interaction of the desire for new experience and many different pathways to these experiences that we hypothesize has an impact on political ideology.

\section{Add Health and Network Properties}

We use data from the National Longitudinal Study of Adolescent Health (Add Health) to examine the moderating influence of friendships on the effect of DRD4 on political ideology.

Genetic markers are available for a sample of 2,574 individuals, including markers that identify alleles of DRD4. In our sample, $62 \%$ have no $7 \mathrm{R}$ alleles, 33\% have one copy of the allele and 5\% have two copies of the allele. The study has been described elsewhere (Fowler, Baker, and Dawes 2008); more detailed description of the study and genetic data can be found in the online appendix at http://journals. cambridge.org/jop and on the study web page (http:// www.cpc.unc.edu/projects/addhealth). Information was gathered in the first wave about a subject's social network. Students were allowed to nominate up to five female and five male friends. We will focus on a simple measure, the number of nonfamilial friends named by the respondent in the first wave.

Nearly $80 \%$ of the sibling-pairs sample participants in Wave I also participated in Wave III. Subjects were young adults (age 18-26) by the time of the third wave and were asked several questions about their political behavior and civic activity. Our dependent variable, self-identified ideology, is ascertained from responses to the question, "In terms of politics, do you consider yourself conservative, liberal, or middle-of-the-road?" Five responses were permitted, "very conservative," "conservative," "middle-of-the-road," "liberal," or "very liberal." This ideology question is well-suited for our purpose of exploring the genetic basis of ideology because of its similarity to standard questions used on the National Election Study survey and other frequently cited surveys (Jost 2006).

\section{Genetic Association}

Genetic association studies test whether an allele or genotype occurs more frequently within a group exhibiting a particular trait than those without the trait (e.g., is the frequency of a particular allele or genotype higher among liberals than conservatives?). Because a significant association has several possible explanations, there are two main research designs 
employed in association studies to isolate the effect of an allele on a trait, case-control designs and familybased designs (Carey 2002). Due to potential population stratification in our sample, we chose to employ a family-based design, which eliminates the problem of population stratification by using family members, such as parents or siblings, as controls. Tests using family data compare whether offspring exhibiting the trait receive a particular allele from their parents more often than would be expected by chance. They do not rely on twins to study genetic variation; any kind of close family relation can be used (siblings, parents, etc.). (See the online appendix for a more detailed explanation of the research design.)

\section{Family-Based Design Methods and Results}

Gauderman (2003) showed that the family-based quantitative disequilibrium transmission test (QTDT) of association (Abecasis, Cardon, and Cookson 2000; Fulker et al. 1999) could be extended to accommodate gene-environment interactions. The model of allelic transmission we employ is:

$$
\begin{aligned}
y_{i j} & =\beta_{0}+\beta_{b} b_{i}+\beta_{w} w_{i j}+\beta_{E} E_{i j}+\beta_{w E} E_{i j} w_{i j} \\
w_{i j} & =g_{i j}-b_{i} \\
& \sum_{j} g_{i j} \\
b_{i} & =\frac{j}{n_{i}}
\end{aligned}
$$

where $y_{i j}$ is the ideology of individual $j$ in family $i, n_{i}$ is the number of family members, $g_{i j}$ is the genotypic score which equals the number of $7 \mathrm{R}$ alleles $(0,1$, or 2$)$, $b_{i}$ is the expected genotypic score, $w_{i j}$ is an individual's deviation from the expected genotypic score, and $E_{i j}$ is the number of friendships an individual self-reports. A positive value for $w_{i j}$ means that a child inherited an excess number of copies of the 7R allele from his or her parents than expected and thus a significant positive value for $\beta_{\mathrm{w}}$ indicates that an excess transmission of $7 \mathrm{R}$ alleles is associated with holding a more liberal ideology. A significant positive value for $\beta_{\mathrm{wE}}$ suggests that this association is moderated by the number of friendships one has.

The QTDT decomposes the genotypic score into two orthogonal components, the between-family component (the expected genotypic score) and the within-family component (the deviation from the genotypic score). The virtue of this design is that while the total association and the between-family component are sensitive to population stratification, which could result in a false signal of association, the within-family component is not (since family members share the same ancestry). Therefore, the QTDT effectively guards against population stratification.

We include individuals from the same family in the analysis, and thus the observations are not independent. Therefore, we use a generalized estimating equations approach with an independent working correlation structure for the clustered errors, to estimate the model. Only siblings that have different genotypes, in this case a different number of $7 \mathrm{R}$ alleles, are informative for the within-family component of variance since $w_{i j}$ equals zero otherwise. However, families that share the same genotype are also included in our analysis for improved estimation of the between-family component. We have also included controls in the model for both age and gender, as there are numerous instances of age effects in gene-environment interactions and there are sexspecific genetic influences on political preferences (Hatemi, Medland, and Eaves 2009c). As is described in the behavior genetics literature (Eaves 1984), a statistical interaction between a gene and the environment will only be present when there is variation in both the gene and the environment. From a statistical perspective, the magnitude of the geneby-environment interaction can be considered the extent to which the average performance of the gene and the environment fail to predict the response of individual combinations of genotypes and environments. When using genetic analysis, however, it may be best to view the interaction as the genetic control of sensitivity to the environment (Eaves 1984).

The results of the model are presented in Table 1.

The parameters of primary interest are $\beta_{\mathrm{w}}$ and $\beta_{\mathrm{wE}}$ because they represent formal tests of association. The estimate of $\beta_{\mathrm{w}}$ is not significant $(p=0.35)$ suggesting that there is not a direct association between the $7 \mathrm{R}$ allele and ideology. However, the estimate of the interaction $\beta_{\mathrm{wE}}$ is significant $(p=0.02)$, meaning that the number of friendships moderates an association between $7 \mathrm{R}$ and ideology. The interpretation of this result is that having more $7 \mathrm{R}$ alleles and more friends is associated with being more liberal. As a further test, we randomly resample our data set 5,000 times with replacement and calculate an empirical $p$-value based on these estimates of $\beta_{\mathrm{wE}}$. The empirical $p$-value is also significant $(p=0.01)$. To be sure that the interaction is not the result of a direct association between $7 \mathrm{R}$ alleles and ideology or friendships, we conduct additional 
TABle 1 Quantitative Disequilibrium Transmission Test of an Association Between DRD4 and Political Ideology, Including an Interaction with Number of Friendships

\begin{tabular}{lcc}
\hline & $\begin{array}{c}\text { Estimate } \\
\text { (standard error) }\end{array}$ & p-value \\
\hline Intercept & $2.84(0.23)$ & 0.00 \\
Between-family & $-0.05(0.04)$ & 0.12 \\
$\quad$ component of DRD4-7R $(b)$ & & \\
Within-family & $-0.11(0.11)$ & 0.35 \\
$\quad$ component of DRD4-7R (w) & & \\
Friendships & $-0.00(0.00)$ & 0.87 \\
Age & $0.00(0.01)$ & 0.67 \\
Male & $-0.05(0.04)$ & 0.16 \\
$w^{*}$ Friendships & $0.04(0.02)$ & 0.02 \\
Deviance & 1116.97 & \\
$N$ & 1941 & \\
\hline
\end{tabular}

Note: This table can be read like an ordinary regression except that the variable coding for DRD4 is divided into two variables to control for population stratification. The between-family component represents the average number of $D R D 4-7 \mathrm{R}$ alleles among all observed members of the subject's family, while the withinfamily component indicates the excess number of DRD4-7R alleles relative to the family average. Null deviance $=1123.28$.

association tests shown in the appendix. The results of these tests indicate that $7 \mathrm{R}$ alleles have no significant effect on the number of friends, and no direct impact on ideology. Only the interaction is significant.

Figure 1 is a graphical representation of the interaction between the presence of the alleles and the number of friendships. For those without any $7 \mathrm{R}$ alleles, the number of friends is not related to liberal ideology. Holding all else constant, for people who have two copies of the allele, an increase in number of friendships from zero to ten friends is associated with increasing ideology in the liberal direction by about $40 \%$ of a category on our five-category scale. In other words, 10 friends can move a person with two copies of the 7R allele almost halfway from being conservative to moderate or from being moderate to liberal.

To address further the nature of the friendship interaction, we report additional analyses in the appendix that demonstrate our results are not being driven by gendered patterns or interactions of friendship and that the results hold when using a dichotomous measure of friendship. We also report the results of the interaction model, but without the interaction term. The residual deviance for this model is higher than the model with the interaction, indicating that the interaction model fits better.

\section{FIgURE 1 Increasing the Number of Friends in People with Two Copies of DRD4-7R is Associated with Increased Self- Reported Liberalism}
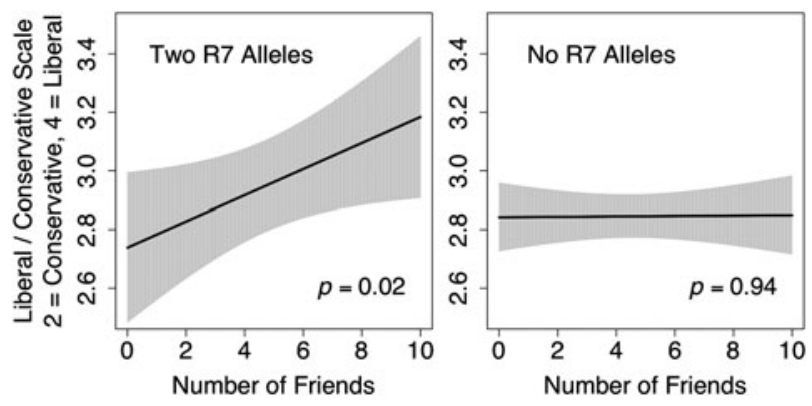

Standard statistical tests of fit do not apply in GEE models (Pan 2002). To be sure the improvement in fit resulting from adding the interaction term to the model was not due to chance, we randomly shuffled the values in the interaction term (leaving the values for all other variables and observations intact) and reran the model, repeating this 1000 times, and measuring the residual deviance each time. The lowest deviance (best fit) out of 1000 tries was 1120.40 . By comparison, the null model produces a deviance of 1123.28 and the interaction model produces a deviance of 1116.97, suggesting the interaction model's improvement in fit has less than a 1 in 1000 chance of being caused by random variation.

\section{Discussion}

For most traits, the effects of individual genes are too small to stand out against the combined influence of all other genes and environmental factors. Thus, our $p$-value of 0.02 on a sample of 2,000 individuals should be treated cautiously. The expectation in genetics is that only repeated efforts to replicate associations on independent samples by several research teams will verify initial findings like these. Thus, perhaps the most valuable contribution of this study is not to declare that "a gene was found" for anything, but rather, to provide the first evidence for a possible gene-environment interaction for political ideology.

Many large-scale analyses of political behaviors ignore the potential for genetic effects. Of those that do not, few offer a model which builds a hypothesis based on social and cultural influences that interact with a specific neurotransmitter that is regulated by a specific genetic marker. It is our hope that more 
scholars will begin to explore the potential interaction of biology and environment, thus leading to the development of consortiums for social and political traits that will allow for the replication or combination of findings across samples.

Given these cautions, we reiterate the main results of our investigation. Using a family-based genetic association study, we find that political ideology in early adulthood is significantly associated with an interaction between a gene previously linked to novelty-seeking behavior (DRD4-7R), and an environmental influence, the number of adolescent friendships. We do not claim that this evidence proves a causal relationship between DRD4 and political ideology. However, the association is consistent with a causal theory that we develop about the way genes and environments combine to affect political ideology.

It is important to note that the $7 \mathrm{R}$ allele by itself does not make a person liberal and neither does simply having a greater number of friends as a teenager. Additionally, the $7 \mathrm{R}$ allele does not cause an individual to have more friends (see the appendix), and twin studies have shown that the number of friends one names is not significantly heritable (Fowler, Dawes, Christakis 2009). Rather, it is the crucial interaction of two factors-the genetic predisposition of having a greater number of $7 \mathrm{R}$ alleles and the environmental condition of having many friends in adolescence-that is associated with being more liberal.

Geneticists are sometimes skeptical of associations where an interaction effect exists and a main effect does not. The reason for this skepticism is a concern with the potential to produce false positive results. If we were testing 100 genes and 100 environmental factors, there would be 10,000 possible interactions, and many of these would yield significant results. However, in our case, the Add Health data contains only eight genes, greatly reducing the number of possible interactions one could test. This does not necessarily reduce the possibility of false positive for a given test, but does offer protection from unreported multiple testing. Political scientists also typically guard against false positives by requiring $e x$ ante theorizing. In our case, we were only interested in DRD4 for political ideology because of its association with novelty-seeking behavior, and we developed an explicit theory that the interaction between DRD4 and friendships-and not the main effectswould be significant. Since our test was not able to contradict the theory, the way forward is to seek replication in different populations and age groups.
While our finding is statistically significant, the strength of the association is quite small. However, even in a biometric trait such as height, less than $15 \%$ of the variation has been attributed to specific genes. Genetic effects take place in complex interaction with other genes and environments, and it is likely the combination of hundreds if not thousands of genes interacting with each other and with external stimuli that influence political attitudes and behavior.

There are several factors that would be instrumental for future replication studies. There is no measure in the Add Health data that has been validated against typical measures of novelty seeking; the questions that are conceptually related in the survey are inappropriate for comparison to other studies which include the behavioral trait in the analysis. If we did have such a measure, we could test the extent to which it accounts for the associations we observe here. Additionally, both number of friends nominated and ideology were single selfreport measures. While we have good reason to believe that self-reported ideology is an accurate representation of a person's true ideological beliefs (Lau and Redlawsk 1997), we are using a standard, but very simple, measure that may not fully capture the breadth and depth of a person's ideological beliefs. Finally, past work suggests that political sophistication plays an important role in the manifestation of ideology (Converse 1964; Sniderman, Brody, and Tetlock 1993), but we cannot address the role that political sophistication might play in our results because there were no reliable measures in Add Health (2007). All of these limitations suggest that we should develop datasets that include genes, psychological questions to create valid constructs, and political data.

In light of these and other findings, political scientists can no longer afford to view ideology as a strictly social construct, perfectly malleable and completely subject to historically changing circumstances. As Jost et al. (2003) suggest, there appears to be both a stable definitional core and changing peripheral associations involved in a conservative political ideology. Our work builds upon this growing literature in psychology and genetics by offering a genetic basis for the link between motivated social cognition and ideology.

Finally, the results here suggest that, contrary to Mannheim's assertion and the body of work that followed him, the social and institutional environment cannot entirely explain a person's political attitudes and beliefs. We must take into account the role of genes and gene-environment interactions in 
the formation and maintenance of political beliefs. Our findings do not undermine the rich body of literature that has developed regarding the environmental influences that shape political behavior. Rather, we hope to complement prior work and seek to show how incorporating a role for specific genes into our models of political behavior can enrich our understanding of the origin and nature of these behaviors. Political scientists have a wealth of material from which to form hypotheses about potential gene-environment interactions that influence deeply held political ideas and values.

\section{Acknowledgments}

This research was supported by National Institute on Aging grant P-01 AG-031093 and National Science Foundation grant SES-0719404. Thanks to Peter K. Hatemi for valuable comments.

Manuscript submitted 16 January 2009

Manuscript accepted for publication 2 November 2009

\section{References}

Abecasis, G., L. Cardon, and W. Cookson. 2000. "A General Test of Association for Quantitative Traits in Nuclear Families." American Journal of Human Genetics 66 (1): 279-92.

Abramovitz, Alan I., and Kyle L. Saunders. 1998. "Ideological Realignment in the U.S. Electorate.” Journal of Politics 60 (3): 634-52.

Add Health Biomarker Team. 2007. "Biomarkers in Wave III of the Add Health Study.” URL: http://www.cpc.unc.edu/projects/ addhealth/files/biomark.pdf.

Alford, John, Carolyn Funk, and John Hibbing. 2005. "Are Political Orientations Genetically Transmitted?" American Political Science Review 99 (2): 153-67.

Auerbach, J. G., M. Faroy, R. Ebstein, M. Kahana, and J. Levine. 2001. "The Association of the Dopamine D4 Receptor Gene (DRD4) and the Serotonin Transporter Promoter Gene (5HTLPR) with Temperament in 12-Month-Old Infants." The Journal of Child Psychology and Psychiatry 42 (6): 777-83.

Bell, Daniel. 1959. The End of Ideology. Glencoe, IL: The Free Press.

Benjamin, J., L. Li, C. Patterson, B. D. Greenberg, D. L. Murphy, and D. H. Hamer. 1996. "Population and Familial Association between the D4 Dopamine Receptor Gene and Measures of Novelty Seeking." Nature Genetics 12 (1): 81-84.

Benjamin, J., Y. Osher, M. Kotler, I. Gritsenko, L. Nemanov, R. H. Belmaker, and R. P. Ebstein. 2000. "Association between Tridimensional Personality Questionnaire Traits and Three Functional Polymorphisms: DrD4, 5-HTTLPR, and COMT." Molecular Psychiatry 5 (1): 96-100.

Berelson, Bernard, Paul F. Lazarsfeld, and William N. McPhee. 1954. Voting. Chicago: University of Chicago Press.
Bishop, J., and H. Inderbitzen. 1995. "Peer Acceptance and Friendship: An Investigation." Journal of Early Adolescence 15 (4): 476-89.

Bouchard, T. J., and M. McGue. 2003. "Genetic and Environmental Influences on Human Psychological Differences." Journal of Neurobiology 54 (1): 4-45.

Campbell, Angus, Philip E. Converse, Warren E. Miller, and Donald E. Stokes. 1960. The American Voter. Chicago: University of Chicago Press: .

Caprara, G. V., C. Barbaranelli, and P. G. Zimbardo. 1999. "Personality Profiles and Political Parties." Political Psychology 20 (1): 175-97.

Carey, Gregory. 2002. Human Genetics for the Social Sciences. New York: Sage Publications.

Carney, Dana R., John T. Jost, and Samuel D. Gosling. 2008. "The Secret Lives of Liberals and Conservatives: Personality Profiles, Interaction Styles, and the Things They Leave Behind." Political Psychology 29 (6): 807-40.

Cloninger, C. R., D. M. Svrakic, and T. R. Przybeck. 1993. "A Psychobiological Model of Temperament and Character." Archives of General Psychiatry 50 (12): 975-90.

Conover, Pamela, and Stanley Feldman. 1981. "The Origins and Meaning of Liberal/Conservative Self-Identification," American Journal of Political Science 25 (4): 617-45.

Converse, Philip E. 1964. "The Nature of Belief Systems in Mass Publics." In Ideology and Discontent, ed. David E. Apter. New York: The Free Press, 206-61.

Cornelis, Ilse, Alain Van Hiel, Arne Roets, and Malgorzata Kossowska. 2009. "Age Differences in Conservatism: Evidence on the Mediating Effects of Personality and Cognitive Style." Journal of Personality 77 (1): 51-88.

Dawes, Christopher T., and James H. Fowler. 2009. "Partisanship, Voting, and the Dopamine D2 Receptor Gene" Journal of Politics 71 (3): 1157-71.

De Fruyt, F., L. Van De Wieleb, and C. Van Heeringen. 2000. "Cloninger's Psychobiological Model of Temperament and Character and the Five-Factor Model of Personality. Personality and Individual Differences 29 (3): 441-52.

De Luca, A., M. Rizzardi, I. Torrente, R. Alessandroni, G. P. Salvioli, N. Filograsso, B. Dallapiccola, G. Novelli. 2001. "Dopamine D4 Receptor Polymorphism and Adaptibility Trait during Infancy: A Longitudinal Study in 1- to 5- Month-Old Neonates." Neurogenetics 3:79-82.

Eaves, Lindon J., and Peter K. Hatemi. 2008. "Transmission of Attitudes toward Abortion and Gay Rights: Parental Socialization or Parental Mate Selection?” Behavior Genetics 38 (3): 247-56.

Eaves, L. J. 1984. "The Resolution of Genotype X Environment Interaction in Segregation Analysis of Nuclear Families." Genet. Epidemiol 1 (3): 215-28.

Eaves, L. J., and H. J. Eysenck. 1974. "Genetics and the Development of Social Attitudes.” Nature 249: 288-89.

Ebstein, R. P., O. Novick, R. Umansky, B. Pirelli, Y. Osher, D. Blaine, E. R. Bennett, L. Nemanov, M. Katz, and R. H. Belmaker. 1996. "Dopamine D4 Receptor Exon III Polymorphism Associated with the Human Personality Trait of Novelty Seeking." Nature Genetics 12: 78-80.

Eichhammer, P., P. G. Sand, P. Sooertebecker, B. Langguth, M. Zowe, and G. Hajak. 2005. "Variation at the DRD4 Promoter Modulates Extraversion in Caucasians." Molecular Psychiatry 10 (6): 520-22. 
Fowler, James H., Laura Baker, and Christopher T. Dawes. 2008. "Genetic Variation in Political Behavior." American Political Science Review 102 (2): 233-48.

Fowler, James H. and Christopher T. Dawes. 2008. "Two Genes Predict Voter Turnout." Journal of Politics 70 (3): 579-94.

Fowler, James H., Christopher T. Dawes, and Nicholas A. Christakis. 2009. "A Model of Genetic Variation in Human Social Networks." Proceedings of the National Academy of Sciences 106 (5).

Fulker, D., S. Cherny, P. Sham, and J. Hewitt. 1999. "Combined Linkage and Association Sib-Pair Analysis for Quantitative Traits." American Journal of Human Genetics 64 (1): 259-67.

Gauderman, W. James. 2003. "Candidate Gene Association Analysis for a Quantitative Trait, Using Parent-Offspring Trios." Genetic Epidemiology 25 (4): 327-38.

Gerring, John. 1997. “Ideology: A Definitional Analysis.” Political Research Quarterly 50 (4): 957-94.

Golimbet, V. E., M. V. Alfimova, I. K. Gritsenko, and R. P. Ebstein. 2007. "Relationship between Dopamine System Genes and Extraversion and Novelty Seeking." Neuroscience and Behavioral Physiology 37 (6): 601-06.

Haas, Peter M. 1992. "Epistemic Communities and International-Policy Coordination-Introduction." International Organization 46 (1): 1-35.

Hartup, W. 1983. "Peer Relations." In ((Handbook of Child Psychology: Vol. 4. Socialization, Personality and Social Development (eds. P. H. Mussen (Series Editor) and E. M. Hetherington (Vo. Editor). New York: John Wiley \& Sons, 103-96.

Hatemi, P. K., S. E. Medland, K. I. Morley, A. C. Heath, and N. G. Martin. 2007. "The Genetics of Voting: An Australian Twin Study.” Behavior Genetics 37 (3): 435-48.

Hatemi, Peter K., John Hibbing, John Alford, Nicholas Martin, and Lindon Eaves. 2009a. "Is There a 'Party' in Your Genes?" Political Research Quarterly 62 (3): 584-600.

Hatemi, P. K., C. Funk, S. E. Medland, H. Maes, J. Silberg, N. G. Martin, and L. J. Eaves. 2009b. "Genetic and Environmental Transmission of Political Attitudes over a Life Time." Journal of Politics 71 (3): 1141-56.

Hatemi, Peter K., Sarah E. Medland, and Lindon J. Eaves. 2009c. "Genetic Sources for the Gender Gap?" Journal of Politics 71 (1): 262-76.

Heiman, Tali. 2000. "Quality and Quantity of Friendship: Students' and Teachers' Perceptions." School Psychology International 21 (3): 265-80.

Hetherington, Marc J. 2001. "Resurgent Mass Partisanship: The Role of Elite Polarization." American Political Science Review 95 (3): 619-31.

Hinich, Melvin J., and Michael C. Munger. 1997. Analytical Politics. Cambridge, MA: Cambridge University Press.

Holbrook, Thomas M. 1996. Do Campaigns Matter? Thousand Oaks, CA: Sage Publications Inc.

Huckfeldt, Robert, Paul Johnson, and John Sprague. 2004. Political Disagreement: The Survival of Diverse Opinions within Communication Networks. New York: Cambridge University Press.

Huntington, Samuel P. 1957. "Conservatism as an Ideology." American Political Science Review 51 (2): 454-73.

Jacobson, Gary. 2003. "Partisan Polarization in Presidential Support: The Electoral Connection." Congress \& The Presidency 30 (1): 1-36.
Jacoby, William. 2004. "Ideology in the 2000 Elections: A Study in Ambivalence." In Models of Voting in Presidential Elections, eds. Herbert F. Weisberg and Clyde Wilcox. Stanford, CA: Stanford University Press, 103-22.

Jennings, M. K. and Richard G. Niemi. 1968. "The Transmission of Political Values from Parent to Child." American Political Science Review 62 (1): 169-84.

Jost, J. T. 2006. "The End of the End of Ideology." American Psychologist 61 (7): 651-70.

Jost, J. T., J. Glaser, A. W. Kruglanski, and F. J. Sulloway. 2003. "Political Conservatism as Motivated Social Cognition." Psychological Bulletin 129 (3): 339-75.

Jost, J. T., and E. P. Thompson. 2000. "Group-Based Dominance and Opposition to Equality as Independent Predictors of SelfEsteem, Ethnocentrism, and Social Policy Attitudes among African Americans and European Americans." Journal of Experimental Social Psychology 36 (3): 209-32.

Kluger, A. N., Z. Siegfried, and R. P. Ebstein. 2002. "A MetaAnalysis of the Association Between DRD4 Polymorphism and Novelty Seeking." Molecular Psychiatry 7 (7): 712-17.

Kruglanski, A. W., and D. M. Webster. 1996. "Motivated Closing of the Mind: 'Seizing' and 'Freezing."' Psychological Review 103 (2): 263-83.

Lau, Richard R., and David P. Redlawsk. 1997. "Voting Correctly." American Political Science Review 91 (3): 585-98.

Lipset, Seymour M. 1983. "Radicalism Or Reformism-The Sources Of Working-Class Politics." American Political Science Review 77 (1): 1-18.

Mackay, T. 2001. "The Genetic Architecture of Quantitative Traits." Annual Review of Genetics 35: 303-39.

Mannheim, Karl. 1936. Ideology and Utopia. London: Routledge.

Martin, N. G., L. J. Eaves, A. C. Heath, Rosemary Jardine, Lynn Feingold, and H. J. Eysenck. 1986. "Transmission of Social Attitudes." Proceedings of the National Academy of Sciences 83 (12): 4364-68.

McCarty, Nolan, Keith Poole, and Howard Rosenthal. 2006. Polarized America: The Dance of Political Ideology and Unequal Riches. Cambridge, MA: MIT Press.

McCrae, Robert R. 1996. "Social Consequences of Experiential Openness.” Psychological Bulletin 120 (3): 323-37.

McPherson, Miller, Lynn Smith-Lovin, and James Cook. 2001. "Birds of a Feather: Homophily in Social Networks." Annual Reviews in Sociology 27: 415-44.

Mondak, Jeffery J., and Karen D. Halperin. 2008. "A Framework for the Study of Personality and Political Behaviour." British Journal of Political Science 38 (2): 335-62.

Mutz, Diana C. 2002. "The Consequences of Cross-Cutting Networks for Political Participation." American Journal of Political Science 46 (4): 838-55.

Neibrzydowski, L. 1995. "Friendship among Adolescents." Paper presented at the biennial meeting of the Society for Research in Child Development, Indianapolis, IN.

Noble, E. P., T. Z. Ozkaragoz, T. L. Ritchie, X. Zhang, T. R. Belin, and R. S. Sparkes. 1998. "D2 and D4 Dopamine Receptor Polymorphisms and Personality. American Journal of Medical Genetics 81 (3): 257-67.

North, Douglass C. 1978. "Structure and Performance-Task Of Economic-History" Journal Of Economic Literature 16 (3): 963-78.

Pan, Wei. 2002. "Goodness-of-fit Tests for GEE with Correlated Binary Data." Scandinavian Journal of Statistics 29 (1): 101-10 
Peterson, B. E., and M. D. Lane. 2001. "Implications of Authoritarianism for Young Adulthood: Longitudinal Analysis of College Experiences and Future Goals." Personality and Social Psychology Bulletin 27 (6): 678-90.

Peterson, B. E., K. A. Smirles, and P. A. Wentworth. 1997. "Generativity and Authoritarianism Implications for Personality, Political Involvement, and Parenting." Journal of Personality and Social Psychology 72 (5): 1202-16.

Plomin, R. 2008. Behavioral Genetics. New York: Worth Publishers.

Pratto, F., J. Sidanius, L. M. Stallworth, and B. F. Malle. 1994. "Social Dominance Orientation: A Personality Variable Predicting Social and Political Attitudes." Journal of Personality and Social Psychology 67 (4): 741-63.

Puttonen, S., N. Ravaja, and L. Keltikangas-Jarvinen. 2005. "Cloninger's Temperament Dimensions and Affective Responses to Different Challenges." Comprehensive Psychiatry 46 (2): 128-34.

Rapoport, Anatol. 1974. Fights, Games, and Debates. Ann Arbor: University Of Michigan Press.

Savitz, J. B. and R. S. Ramesar. 2004. "Genetic Variants Implicated in Personality: a Review of the More Promising Candidates." American Journal of Medical Genetics (Neuropsychiatry Genetics) 131B (1): 20-32.

Schinka, J. A., E. A. Letsch, and F. C. Crawford. 2002. "DRD4 and Novelty Seeking: Results of Meta Analyses." American Journal of Medical Genetics (Neuropsychiatric Genetics) 114 (6): 643-48.

Schmidt, L. A., N. A. Fox, K. H. Rubin, S. Hu, D. H. Hamer. 2002. "Molecular Genetics of Shyness and Aggression in Preschoolers." Perspectives on Individual Differences 33 (2): 227-38.

Schreckhise, William D., and Todd Shields. 2003. "Ideological Realignment in the Contemporary United States Electorate Revisited." Social Science Quarterly 84 (3): 596-613.

Selman, R. L. 1990. "Fostering Intimacy and Autonomy." In (Child Development Today and Tomorrow, ed. W. Damon. San Francisco: Jossey-Bass, 409-35.

Settle, Jaime, Christopher T. Dawes, and James H. Fowler. 2009. "The Heritability of Partisan Attachment." Political Research Quarterly 62 (3): 601-13.

Settle, Jaime E., Robert Bond, and Justin Levitt. 2009. "The Social Origins of Adult Political Behavior." American Politics Research, forthcoming.

Sniderman, Paul M., Richard A. Brody, and Philip E. Tetlock. 1993. Reasoning and Choice: Explorations in Political Psychology. New York: Cambridge University Press.

Staub, D. 1995. "Qualitative Research on School Inclusion: What Do We Know? What Do We Need to Find?" Paper presented at the annual conference of the Association for Persons with Severe Handicaps, San Francisco.

Strobel, A., A. Wehr, A. Michel, and B. Brocke. 1999. "Association between the Dopamine D4 Receptor Exon III Polymorphism and Measures of Novelty Seeking in a German Population. Molecular Psychiatry 4 (4): 378-84.
Tesser, Abraham. 1993. "The Importance of Heritability in Psychological Research: The Case of Attitudes.” Psychological Review. 100 (1): 129-142.

Tomitaka, M., S. Tomitaka, Y. Otuka, K. Kim, H. Matuki, K. Sakamoto, and A. Tanaka. 1999. "Association between Novelty Seeking and Dopamine Receptor D4 (DRD4) Exon III Polymorphism in Japanese Subjects." American Journal of Medical Genetics (Neuropsychiatry Genetics) 88 (5): 469-71.

Trapnell, P. D. 1994. “Openness versus Intellect: A Lexical Left Turn.” European Journal of Personality 8 (4): 273-90.

Treier, Shawn, and Sunshine Hillygus. 2005. "The Structure and Meaning of Political Ideology." Working Paper. University of Georgia.

Van Hiel, Alain, Malgorzata Kossowska, and Ivan Mervielde. 2000. "The Relationship between Openness to Experience and Political Ideology." Personality and Individual Differences, 28 (4): 741-51

Van Tol, H. H. M., C. M. Wu, H.-C. Guan, K. Ohara, J. R. Bunzow, O. Civelli, J. Kennedy, P. Seeman, H. B. Niznik, and V. Jovanovic. 1992. "Multiple Dopamine D4 Receptor Variants in the Human Population." Nature 358: 149-52.

Verhulst, Brad, Lindon J Eaves, and Peter K Hatemi. 2009. "Personality Traits and Political Ideologies." Paper presented at the annual Behavior Genetics Conference, Minneapolis.

White, K. M., J. C. Speisman, D. Costos, and A. Smith. 1987. "Relationships Maturity: A Conceptual and Empirical Approach.” In J. Meacham (ed.) International Relations: Family, Peers, Friends. Basel: Switzerland, Karger, 81-101.

Wiesbeck, G. A., C. Mauerer, J. Thome, F. Jacob, J. Boening. 1995. "Neuroendocrine Support for a Relationship between "Novelty Seeking" and Dopaminergic Function in AlcoholDependent Men." Psychoneuroendocrinology 20: 755-761.

Jaime E. Settle is a Ph.D. candidate in the Department of Political Science, University of California, San Diego, 9500 Gilman Drive 0521, La Jolla, CA 92093-0521.

Christopher T. Dawes is a Ph.D. candidate in the Department of Political Science, University of California, San Diego, 9500 Gilman Drive 0521, La Jolla, CA 92093-0521.

Nicholas A. Christakis is a Professor of Health Care Policy, Harvard Medical School, and Department of Sociology, Harvard University, Cambridge, MA 02138.

James H. Fowler is a Professor of Genetics in the School of Medicine and Professor of Political Science in the Division of Social Sciences, University of California, San Diego, 9500 Gilman Drive 0521, La Jolla, CA 92093-0521. 